\title{
Intraneural Synovial Sarcoma Originating From the Median Nerve
}

\author{
-Case Report-
Hisao UEHARA, Koji YAMASAKI, Tsuyoshi FUKUSHIMA* , Atsushi YAMASHITA**, Kosuke MARUTSUKA**, Shinichi NAKANO***, Yujiro ASADA**, and Hideo TAKESHIMA

\begin{abstract}
Division of Neurosurgery, Department of Clinical Neuroscience, and Divisions of * Oncopathology and Regenerative Biology and **Pathophysiology, Department of Pathology, Faculty of Medicine, University of Miyazaki, Miyazaki; *** Department of Neurosurgery, Kanemaru Neurosurgical Hospital, Miyazaki
\end{abstract}

\begin{abstract}
A 33-year-old female presented with a rare synovial sarcoma manifesting as a painful $12 \times 15 \mathbf{m m}$ tumor in the median palmar carpus. Preoperative neurological examination detected only radiating spontaneous pain in her right radial palm and decreased right grasping power. Magnetic resonance (MR) imaging confirmed the presence of the tumor. The preoperative diagnosis was schwannoma originating from the right median nerve. Subcapsular removal of the tumor was performed for preservation of the nerve function. However, postoperative histological and immunohistochemical studies suggested synovial sarcoma originating from the median nerve. No systemic metastasis was detected and the residual tumor capsule was totally removed. Local radiation therapy of $40 \mathrm{~Gy}, 2 \mathrm{~Gy}$ per day, was administered. Fourteen months later, local recurrence was detected on MR imaging. Total removal of the recurrent tumor was performed. Synovial sarcoma was finally diagnosed by the identification of SYTSSX1 fusion gene transcripts using reverse transcriptase-polymerase chain reaction with a frozen tumor tissue sample.
\end{abstract}

Key words: intraneural synovial sarcoma, median nerve, SYT-SSX fusion gene

\section{Introduction}

Synovial sarcoma occurs in the extremities in $80 \%$ of cases, especially around the knee joint. ${ }^{3)}$ This clinical characteristic and the histological resemblance to normal synovium has suggested that synovial sarcoma originates from the synovium. However, synovial sarcoma may arise from any soft tissues of the body, and synovial sarcoma occurs in an articular cavity in only $5 \%$ of cases. Therefore, the origin has remained unclear. ${ }^{19)}$ Synovial sarcoma may have a neural origin because synovial sarcoma and malignant peripheral nerve sheath tumor (MPNST) are difficult to distinguish based on the histological features. ${ }^{13)}$ Alternatively, synovial sarcoma originates from Schwann cell associated with the neural crest based on analysis of the gene expression pattern. ${ }^{26)}$

Received May 28, 2007; Accepted November 12, 2007
However, only 10 cases of intraneural synovial sarcoma have been reported. $2,4,6,16,20,21,23,25,29)$

We treated an adult female with a synovial sarcoma originating from the right median nerve at the right wrist, which was preoperatively diagnosed as schwannoma.

\section{Case Report}

A 33-year-old female presented with a 2-year history of a painful tumor in the right median palmar carpus. The radiating pain spread progressively from the base of her right thumb to the right radial palm. Atrophy of the right thenar muscles also developed. Examination at several orthopedic hospitals failed to establish a diagnosis so she was finally referred to our department.

On admission, physical examination demonstrated a palpable painful elastic hard tumor $12 \times 15 \mathrm{~mm}$ in size in the right palmar median wrist. Neurologi- 

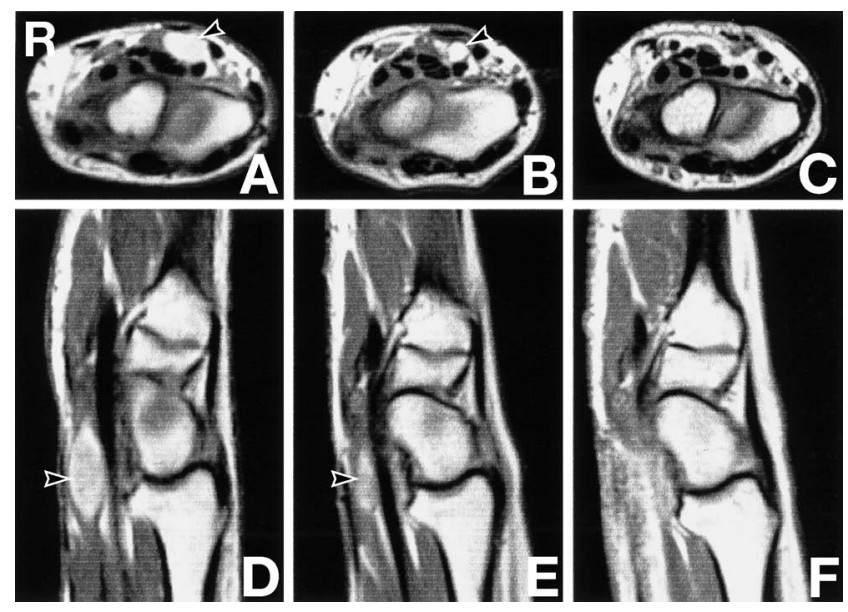

Fig. 1 A, D: Axial (A) and sagittal (D) $\mathrm{T}_{1}$-weighted magnetic resonance (MR) images with contrast medium before first surgery in December 2004 showing a well-enhanced mass (arrowhead) corresponding to the right median nerve just beneath the tendon of the right musculus palmaris longus at the right wrist. B, E: Axial (B) and sagittal (E) $\mathrm{T}_{1}$-weighted MR images with contrast medium in September 2006 showing a recurrent tumor (arrowhead) corresponding to the initial tumor location. C, F: Axial (C) and sagittal (F) $\mathrm{T}_{\mathbf{1}^{-}}$ weighted $M R$ images with contrast medium after the third operation in October 2006 showing no residual tumor.

cal examination identified radiating pain in the right radial palm without objective sensory disturbance. Her grasping power had decreased to $11 \mathrm{~kg}$ in the right hand compared to $19 \mathrm{~kg}$ in the left hand. Weakness of the right musculus opponens pollicis was also noted. Magnetic resonance (MR) imaging demonstrated a uniformly well-enhanced spindleshaped tumor corresponding to the right median nerve just beneath the tendon of right musculus palmaris longus at the palmar median wrist (Fig. 1A, D). The preoperative diagnosis was schwannoma originating from the right median nerve.

Subcapsular removal of the tumor was performed under local intravenous anesthesia to try to preserve the median nerve function. Postoperatively, she had only faint hypesthesia in the right thumb and index finger. Histological examination showed the tumor consisted of spindle-shaped cells with hyperchromatic dysplastic nuclei arranged in a fascicular pattern (Fig. 2A, B). Immunohistochemical studies demonstrated that some of the tumor cells were positive for S-100 protein (Fig. 2C). Scattered staining for epithelial markers, CK7, pancytokeratin (Fig. 2D), and epithelial membrane antigen (EMA) (Fig.

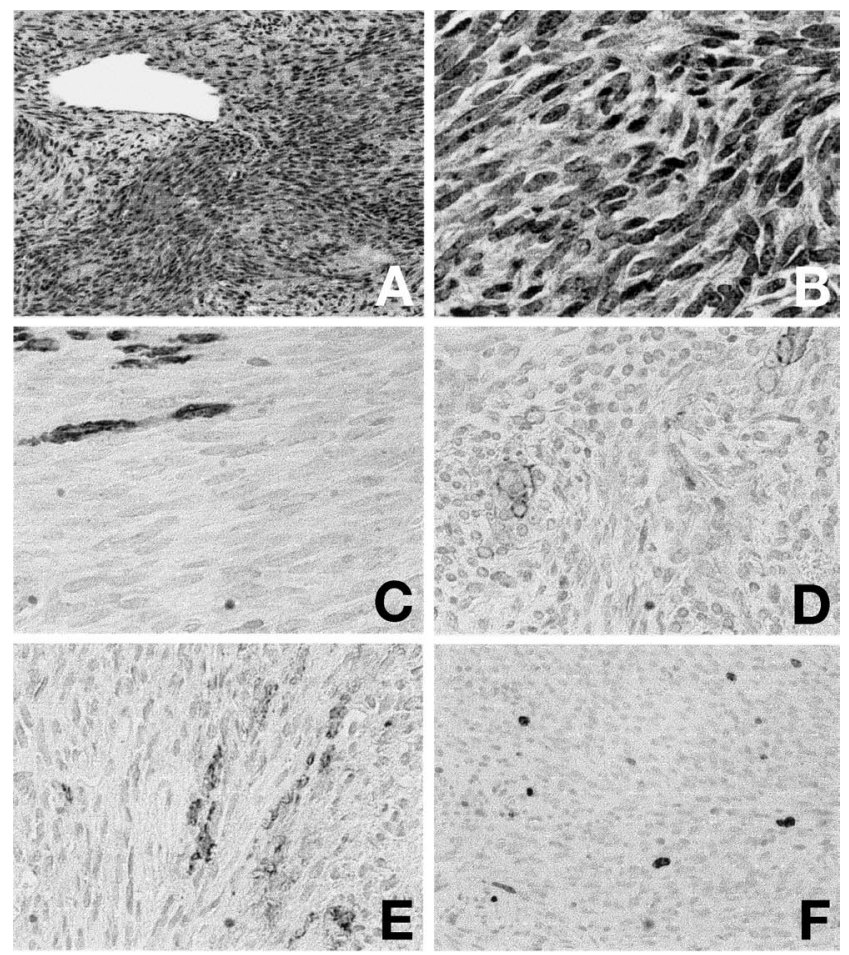

Fig. 2 A, B: Photomicrographs of the initial surgical specimen showing proliferation of spindle-shaped tumor cells with hyperchromatic plump nuclei in a loose fascicular pattern with hypercellularity. Hematoxylin-eosin stain, A: $\times 100$, B: $\times 400$. C-F: Photomicrographs of immunohistochemical staining demonstrating some tumor cells were positive for S-100 protein (C), cytokeratin (D), epithelial membrane antigen (E), and Ki-67 (F). $\times 400$.

2E) were also observed. The histological diagnosis was synovial sarcoma. The Ki-67 labeling index was $2.9 \%$ (Fig. 2F). Detection of SYT-SSX fusion gene transcripts was attempted using the reverse transcriptase-polymerase chain reaction (RT-PCR) in a paraffin-embedded tissue sample, but was unsuccessful. There was no evidence of any systemic metastasis.

Second surgery was performed to remove the residual tumor capsule. Histological examination identified no tumor tissue. She was treated with local irradiation using a dose of $40 \mathrm{~Gy}$. She was followed up by MR imaging every 3 months. A $5 \times 10$ $\mathrm{mm}$ recurrent tumor corresponding to the original region was detected 14 months after the initial operation (Fig. 1B, E). She was readmitted and total removal of the recurrent tumor was performed. Several nerve bundles originating from the right me- 


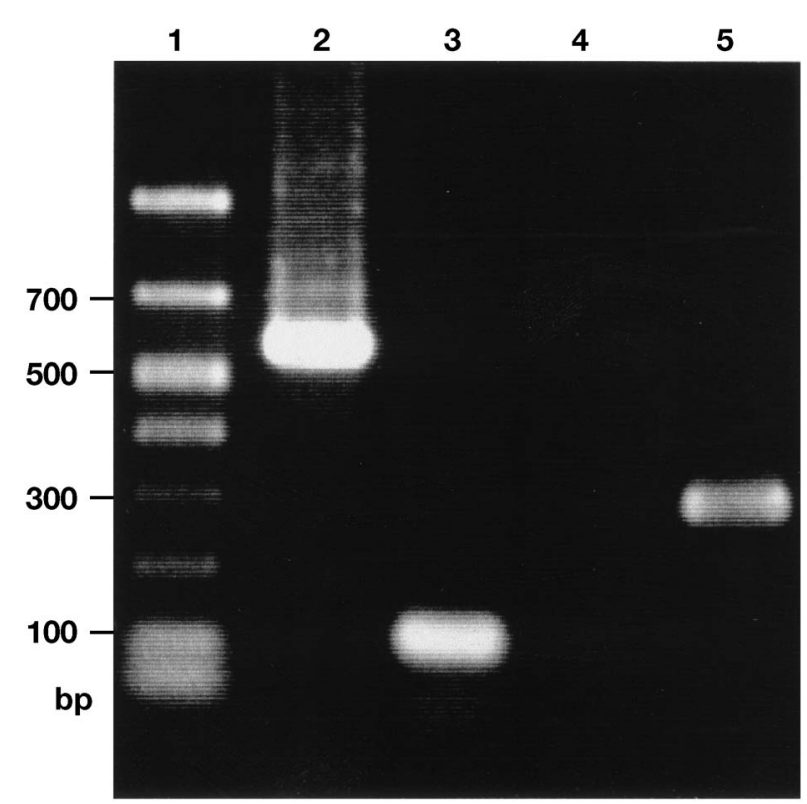

Fig. 3 Reverse transcriptase-polymerase chain reaction for SYT-SSX fusion gene in the frozen recurrent tumor detected SYT-SSX1 translocation (lane 3) but not SYT-SSX2 translocation (lane 4). Lane 1: molecular weight markers, 2: SYT-SSX (585 bp), 3: SYT-SSX1 (118 bp), 4: SYT-SSX2 (118 bp), 5: glyceraldehyde-3-phosphate-dehydrogenase (300 bp). dian nerve and attached to the tumor capsule were identified during the operation, and electrical stimulation confirmed that some were motor components. The motor nerve bundles were carefully preserved and the recurrent tumor was then totally removed with the other sensory bundles of the median nerve. Histological examination of the removed tumor demonstrated tumor tissue growing around the nerve bundles of the median nerve. Postoperative MR imaging demonstrated total removal of the recurrent tumor (Fig. 1C, F). SYT-SSX1 fusion gene transcripts were detected using RT-PCR in a frozen tumor tissue sample (Fig. 3), which confirmed the final diagnosis of synovial sarcoma.

\section{Discussion}

Intraneural synovial sarcoma is very rare, and including this case, originated from the median nerve in three cases, the radial nerve and spinal root in two cases each, and the brachial plexus, peroneal, posterior tibialis, and facial nerves in one case each (Table 1). ${ }^{2,4,6,16,20,21,23,25,29)}$ The macro- and microscopic observations in the present case, especially in the recurrent tumor growing from the median nerve, were consistent with the observation that synovial sarcoma can develop in any soft tissue of the body from neural origins.

Accurate diagnosis of synovial sarcoma was difficult until few years ago. Histological examina-

Table 1 Summary of 11 cases of intraneural synovial sarcoma

\begin{tabular}{|c|c|c|c|c|c|c|c|c|c|c|c|c|}
\hline \multirow{2}{*}{$\begin{array}{c}\text { Case } \\
\text { No. }\end{array}$} & \multirow{2}{*}{ Author (Year) } & \multirow{2}{*}{$\begin{array}{l}\text { Age } \\
\text { (yrs)/ } \\
\text { Sex }\end{array}$} & \multirow[b]{2}{*}{ Nerve } & \multirow{2}{*}{$\begin{array}{c}\text { Histological } \\
\text { type }\end{array}$} & \multicolumn{5}{|c|}{ Immunohistochemistry } & \multirow{2}{*}{$\begin{array}{l}\text { Gene } \\
\text { type }\end{array}$} & \multirow{2}{*}{$\begin{array}{l}\text { Sur- } \\
\text { gery }\end{array}$} & \multirow[b]{2}{*}{ Radiation } \\
\hline & & & & & EMA & VIM & $\begin{array}{l}\text { KRT, } \\
\text { CK }\end{array}$ & $\begin{array}{c}\mathrm{S}-100 \\
\text { protein }\end{array}$ & CD99 & & & \\
\hline 1 & $\begin{array}{l}\text { Cugola and Pisa } \\
(1985)^{6)}\end{array}$ & $16 / \mathrm{F}$ & radial & biphasic & + & + & + & + & & - & ER & - \\
\hline 2 & $\begin{array}{l}\text { Rinehart et al. } \\
(1989)^{21)}\end{array}$ & $23 / F$ & median & monophasic & & & & & & - & ER & - \\
\hline 3 & $\begin{array}{l}\text { O'Connell et al. } \\
(1996)^{20)}\end{array}$ & $16 / F$ & $\begin{array}{r}\text { common } \\
\text { digital }\end{array}$ & biphasic & + & + & + & - & & - & ER & - \\
\hline 4 & $\begin{array}{l}\text { Tacconi et al. } \\
(1996)^{25)}\end{array}$ & $44 / \mathrm{F}$ & $\begin{array}{l}\text { brachial } \\
\text { plexus }\end{array}$ & monophasic & + & + & + & \pm & & - & $\mathrm{TR}$ & + \\
\hline 5 & $\underset{(1997)^{23)}}{\text { Spielmann et al. }}$ & $43 / \mathrm{M}$ & $\begin{array}{r}\text { posterior } \\
\text { tibialis }\end{array}$ & monophasic & + & + & + & - & + & SYT-SSX & A & - \\
\hline 6 & $\begin{array}{l}\text { Chesser et al. } \\
(1999)^{2)}\end{array}$ & $16 / \mathrm{ND}$ & median & biphasic & & + & + & & & - & $\mathrm{TR}$ & + \\
\hline 7 & $\begin{array}{l}\text { Zenmyo et al. } \\
(2001)^{29)}\end{array}$ & $58 / F$ & S1 root & monophasic & + & + & + & + & & SYT-SSX1 & $\mathrm{TR}$ & - \\
\hline 8 & $\begin{array}{l}\text { Lestou et al. } \\
(2002)^{16)}\end{array}$ & $54 / \mathrm{M}$ & peroneal & monophasic & + & + & + & + & + & SYT-SSX2 & $\mathrm{TR}$ & - \\
\hline 9 & $\begin{array}{l}\text { Chu et al. } \\
(2004)^{4}\end{array}$ & $46 / F$ & facial & biphasic & + & + & + & - & - & SYT-SSX & ER & + \\
\hline 10 & & $11 / \mathrm{F}$ & C7 root & monophasic & - & + & - & - & + & SYT-SSX & TR & $+($ proton $)$ \\
\hline 11 & Present case & $33 / F$ & median & monophasic & + & \pm & + & + & & SYT-SSX1 & TR & + \\
\hline
\end{tabular}

A: amputation, CK: cytokeratin, EMA: epithelial membrane antigen, ER: extended resection, KRT: keratin, TR: tumor resection, VIM: vimentin. 


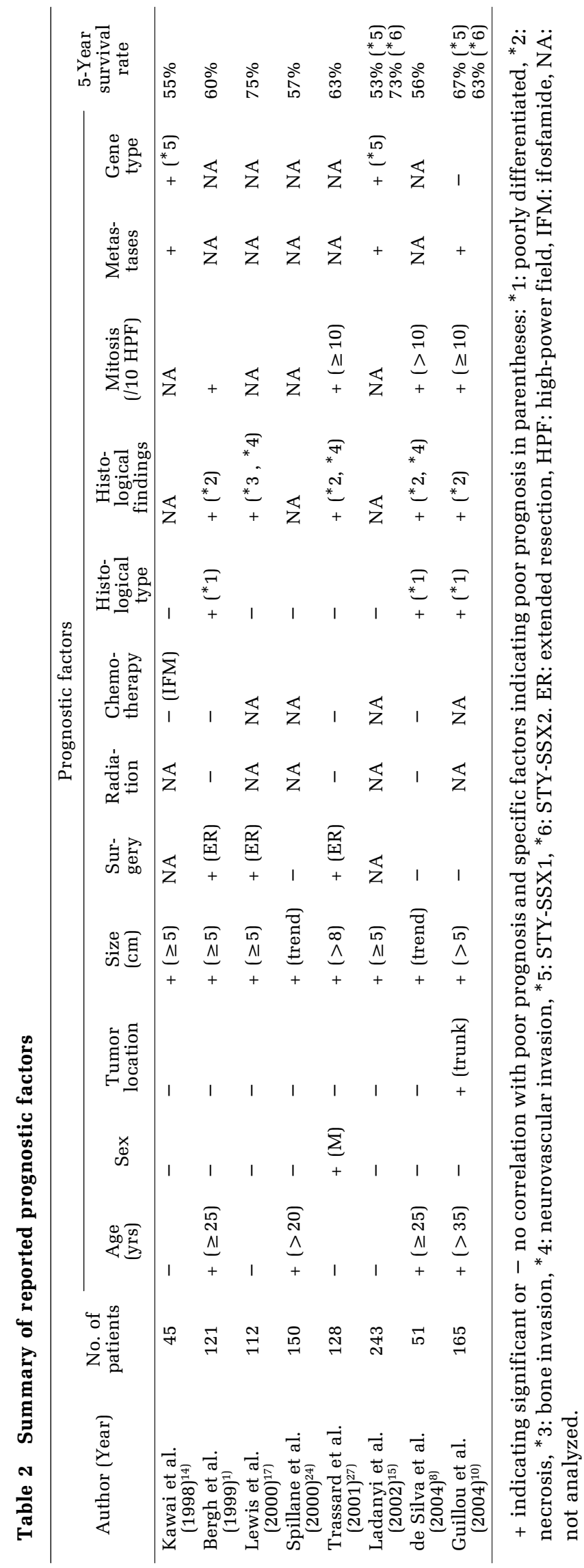

tion has identified two types of cells in synovial sarcoma, spindle-shaped or fibroblast-like cells, and cells resembling epithelial cells. In addition, two histological types of synovial sarcoma have been identified, a biphasic type consisting of a mixture of both spindle-shaped and epithelial cells, and a monophasic type consisting of one or the other type of cells. Furthermore, a poorly differentiated type consisting of less-differentiated cells is sometimes identified. Monophasic types of synovial sarcoma were dominant in the intraneural group (Table 1).

The epithelial cells are positively stained using antibodies for epithelial markers, such as keratin or EMA, but are sparsely stained for S-100 protein. According to such immunohistochemical findings, the biphasic type of synovial sarcoma is easily distinguished from schwannoma and MPNST. On the other hand, the monophasic type of synovial sarcoma and MPNST are often more difficult to distinguish because immunohistochemical staining for epithelial markers is fainter than in the biphasic type. Immunohistochemical staining for CK7 and CK19 were both positive in 23 of 29 cases of synovial sarcoma, but are negative in MPNST tissue. ${ }^{22)}$ About $60 \%$ of synovial sarcomas are immunohistochemically stained for CD99. ${ }^{7)}$

A specific gene translocation between chromosome 18 and chromosome X has been identified in synovial sarcoma. ${ }^{18,28)}$ The SYT-SSX fusion gene is a chimera gene resulting from a translocation. ${ }^{5)}$ This fusion gene was recently determined to be a cause of synovial sarcoma. In addition, two subtypes of the fusion gene have been identified, SYT-SSX1 and SYT-SSX2, and the histological type of synovial sarcoma and the subtypes of the fusion gene are correlated. All cases of the biphasic type express SYTSSX1, whereas half of cases of the monophasic type express the SYT-SSX1, and the other half express SYT-SSX2. ${ }^{14)}$ Therefore, the detection of transcripts of the SYT-SSX gene by RT-PCR is the most useful and reliable tool for the diagnosis of synovial sarcoma. ${ }^{9,12)}$ RT-PCR products were obtained in 221 of 250 cases from paraffin-embedded tissue samples $(88.4 \%)$ and transcripts of SYT-SSX gene were detected in 77 of 80 samples (96.2\%) with histological diagnoses of synovial sarcoma. ${ }^{11)}$ In the present study, fusion gene transcripts could not be detected using the paraffin-embedded tissue sample obtained at first operation, but were isolated using the frozen specimen of the recurrent tumor.

The established treatment for synovial sarcoma is expanded resection within $5 \mathrm{~cm}$ from the tumor margin. There is no significant evidence that resection over $5 \mathrm{~cm}$ from the tumor margin or amputation is ever indicated. The efficacy and optimal dose of 
radiation therapy is not clear. ${ }^{1,8,27)}$ Synovial sarcoma seems to be sensitive to chemotherapy. Ifosfamide has been the primary agent used worldwide, but no convincing evidence of its efficacy has been reported. $1,8,14,27)$

The 5-year survival rates and prognostic factors of synovial sarcoma are summarized in Table $2.1,8,10,14,15,17,24,27)$ The 5 -year survival rate is $50-70 \%$. Good prognostic factors include a tumor size less than $5 \mathrm{~cm}$, age less than 25-30 years old, and histological findings without necrosis, bone invasion, or neurovascular invasion. In contrast, sex and tumor location such as the trunk or extremity had no correlation with the prognosis. Expression of the SYTSSX2 fusion gene type was associated with a better prognosis than expression of SYT-SSX1. ${ }^{14,15)}$ In contrast, no difference was found between the fusion gene types, but had poor prognosis was associated with the poorly differentiated type. ${ }^{1,8,10)}$

Our patient is now being followed up by MR imaging every 3 months, based on the recommendations of an orthopedic cancer specialist, regardless of the marginal tumor resection and monophasic type with SYT-SSX1 fusion gene, because the sizes of both initial and recurrent tumors were smaller than $1.5 \mathrm{~cm}$ and the Ki-67 labeling index was $2.9 \%$.

\section{Acknowledgments}

We deeply thank Dr. Masazumi Tuneyoshi, Department of Pathology, Kyushu University, Fukuoka, for his valuable comments on this case and Dr. Hirokazu Cyuman, Department of Orthopedic Surgery, National Cancer Center, Tokyo, for his suggestion of the patient's treatment.

\section{References}

1) Bergh P, Meis-Kindblom JM, Gherlinzoni F, Berlin Ö, Bacchini P, Bertoni F, Gunterberg B, Kindblom LG: Synovial sarcoma: identification of low and high risk groups. Cancer 85: 2596-2607, 1999

2) Chesser TJS, Geraghty JM, Clarke AM: Intraneural synovial sarcoma of the median nerve. J Hand Surg 24B: 373-375, 1999

3) Christopher DM, Fletcher K, Krishnan U, Fredrik M: World Health Organization Classification of Tumours: Pathology \& Genetic: Tumours of Soft Tissue and Bone, ed 4. Lyon, IARC Press, 2000, pp 200-204

4) Chu PG, Benhattar J, Weiss LM, Meagher-Villemure K: Intraneural synovial sarcoma: two cases. Mod Pathol 17: 258-263, 2004

5) Clark J, Rocques PJ, Crew AJ, Gill S, Shipley J, Chan AM, Gusterson BA, Cooper CS: Identification of novel genes, SYT and SSX, involved in the $\mathrm{t}(\mathrm{X} ; 18)(\mathrm{p} 11.2 ; \mathrm{q} 11.2)$ translocation found in human synovial sarcoma. Nat Genet 7: 502-508, 1994

6) Cugola L, Pisa R: Synovial sarcoma: with radial nerve involvement. J Hand Surg 9: 243-244, 1985

7) Dei Tos AP, Wadden C, Calonje E, Sciot R, Pauwels P, Knight JC, Dal Cin P: Immunohistochemical demonstration of glycoprotein p30/32 ${ }^{\mathrm{MIC} 2}$ (CD99) in synovial sarcoma. Appl Immunohistochem 3: 168-173, 1995

8) de Silva MV, McMahon AD, Reid R: Prognostic factors associated with local recurrence, metastases, and tumor-related death in patients with synovial sarcoma. Am J Clin Oncol 27: 113-121, 2004

9) Fukuoka K: Molecular detection of SYT-SSX fusion gene transcripts currently represents the most specific and sensitive tool for diagnosing intrathoracic synovial sarcoma. Intern Med 45: 881-882, 2006

10) Guillou L, Benhattar J, Bonichon F, Gallagher G, Terrier P, Stauffer E, de Saint Aubain Somerhausen N, Michels JJ, Jundt G, Vince DR, Taylor S, Genevay M, Collin F, Trassard M, Coindre JM: Histologic grade, but not SYT-SSX fusion type, is an important prognostic factor in patients with synovial sarcoma: a multicenter, retrospective analysis. J Clin Oncol 22: 4040-4050, 2004

11) Guillou L, Coindre J, Gallagher G, Terrier P, Gebhard S, de Saint Aubain Somerhausen N, Michels J, Jundt G, Vince DR, Collin F, Trassard M, Le Doussal V, Benhattar J: Detection of the synovial sarcoma translocation $t(X ; 18)(S Y T$;SSX) in paraffin-embedded tissues using reverse transcriptase-polymerase chain reaction: a reliable and powerful diagnostic tool for pathologists. A molecular analysis of 221 mesenchymal tumors fixed in different fixatives. Hum Pathol 32: 105-112, 2001

12) Hiraga $H$, Nojima $T$, Abe $S$, Sawa $H$, Yamashiro $K$, Yamawaki S, Kaneda K, Nagashima K: Diagnosis of synovial sarcoma with the reverse transcriptasepolymerase chain reaction: analyses of 84 soft tissue bone tumors. Diagn Mol Pathol 7: 102-110, 1998

13) Ichinose H, Powell L, Hoerner HE, Derbes VJ, Byers JF: The potential histogenic relationship of the peripheral nerve to synovioma. Cancer Res 39: 4270-4273, 1979

14) Kawai A, Woodruff J, Healey JH, Brennan MF, Antonescu CR, Ladanyi M: SYT-SSX gene fusion as a determinant of morphology and prognosis in synovial sarcoma. N Engl J Med 338: 153-160, 1998

15) Ladanyi M, Antonescu CR, Leung DH, Woodruff JM, Kawai A, Healey JH, Brennan MF, Bridge JA, Neff JR, Barr FG, Goldsmith JD, Brooks JS, Goldblum JR, Ali SZ, Shipley J, Cooper CS, Fisher C, Skytting B, Larsson O: Impact of SYT-SSX fusion type on the clinical behavior of synovial sarcoma: a multi-institutional retrospective study of 243 patients. Cancer Res 62: 135-140, 2002

16) Lestou VS, O’Connell JX, Robichaud M, Salski C, Mathers J, Maguire J, Chudoba I, Sorensen PH, Lam W, Horsman DE: Cryptic t(X;18), ins(6;18), and SYTSSX2 gene fusion in a case of intraneural monophas- 
ic synovial sarcoma. Cancer Genet Cytogenet 138: 153-156, 2002

17) Lewis JJ, Antonescu CR, Leung DH, Blumberg D, Healey JH, Woodruff JM, Brennan MF: Synovial sarcoma: a multivariate analysis of prognostic factors in 112 patients with primary localized tumors of the extremity. J Clin Oncol 18: 2087-2094, 2000

18) Limon J, Dal Cin P, Sandberg AA: Translocations involving the $\mathrm{X}$ chromosome in solid tumors: presentation of two sarcomas with $t(X ; 18)(q 13 ; p 11)$. Cancer Genet Cytogenet 23: 93, 1986

19) Miettinen M, Virtanen I: Synovial sarcoma - a misnomer. Ann J Pathol 117: 18-25, 1984

20) O’Connell JX, Browne WL, Gropper PT, Berean KW: Intraneural biphasic synovial sarcoma: an alternative "glandular" tumor of peripheral nerve. Mod Pathol 9: 738-741, 1996

21) Rinehart GC, Mustoe TA, Weeks PM: Management of synovial sarcoma of the median nerve at the elbow. Plast Reconstr Surg 83: 528-532, 1989

22) Smith TA, Machen SK, Fisher C, Goldblum JR: Usefulness of cytokeratin subsets for distinguishing monophasic synovial sarcoma from malignant peripheral nerve sheath tumor. Am J Clin Pathol 112: 641-648, 1999

23) Spielmann A, Janzen DL, O’Connell JX, Munk PL: Intraneural synovial sarcoma. Skeletal Radiol 26: 677-681, 1997

24) Spillane AJ, A'Hern R, Judson IR, Fisher C, Thomas $\mathrm{M}$ : Synovial sarcoma: a clinicopathologic, staging, and prognostic assessment. J Clin Oncol 18:
3794-3803, 2000

25) Tacconi L, Thom M, Thomas DG: Primary monophasic synovial sarcoma of the brachial plexus: report of a case and review of the literature. Clin Neurol Neurosurg 98: 249-252, 1996

26) Toguchida J, Nagayama S, Okamoto T, Nakamura T, Nakamura Y: [Cellular origin of synovial sarcoma]. Kotsu Kansetsu Jintai 17: 145-148, 2004 (Jpn)

27) Trassard $M$, Le Doussal V, Hacène $K$, Terrier $P$, Ranchère D, Guillou L, Fiche M, Collin F, Vilain MO, Bertrand G, Jacquemier J, Sastre-Garau X, Bui NB, Bonichon F, Coindre JM: Prognostic factors in localized primary synovial sarcoma: a multicenter study of 128 adult patients. J Clin Oncol 19: 525-534, 2001

28) Turc-Carel C, Dal Cin P, Limon J, Li F, Sandberg AA: Translocation X; 18 in synovial sarcoma. Cancer Genet Cytogenet 23: 87-91, 1986

29) Zenmyo M, Komiya S, Hamada T, Hiraoka K, Nagata $\mathrm{K}$, Tsuji S, Hashimoto $\mathrm{H}$, Inoue A: Intraneural monophasic synovial sarcoma: a case report. Spine 26: 310-313, 2001

Address reprint requests to: Hisao Uehara, M.D., Division of Neurosurgery, Department of Clinical Neuroscience, Faculty of Medicine, University of Miyazaki, 5200 Kihara, Kiyotake-cho, Miyazakigun, Miyazaki 889-1692, Japan.

e-mail: huehara@med.miyazaki-u.ac.jp 